\title{
Hyperkalaemia and cardiac conduction block: an initial presentation of chronic kidney disease mimicking cardiac emergency
}

\author{
Ashish Jindal @ , Selvam Suresh, Prashiddha Dhakal, Ashok Kumar Pannu
}

Department of Internal

Medicine, Postgraduate Institute of Medical Education and Research (PGIMER), Chandigarh, India

\section{Correspondence to}

Dr Ashok Kumar Pannu; gawaribacchi@gmail.com

Accepted 24 August 2021

\section{DESCRIPTION}

A 60-year-old woman without previous comorbidities presented to the emergency department with acute onset difficulty breathing and dizziness for few hours. She reported of diffuse abdominal pain, vomiting and reduced urine output for 2 weeks. At admission, the pulse was 86 per minute and irregular and blood pressure was 146/74 mm Hg. Electrocardiography (ECG) revealed irregular, wide QRS escape rhythms with no distinct $\mathrm{P}$ waves and peaked T waves (figure 1). Initially, a possibility of complete heart block was kept in the background of advanced age and hypertension. However, biochemistry panel showed serum potassium of $8.0 \mathrm{mEq} / \mathrm{L}$ (normal, 3.5-5.0) and serum creatinine $21.0 \mathrm{mg} / \mathrm{dL}$ (normal, 0.6-1.2). She had metabolic acidosis ( $\mathrm{pH}$ 7.27 and bicarbonate $10.7 \mathrm{mmol} / \mathrm{L}$ ) and anaemia (haemoglobin $79 \mathrm{~g} / \mathrm{L}$ ). Ultrasonography revealed bilateral small kidneys $(7.5 \mathrm{~cm}$ and $8.0 \mathrm{~cm})$ with lost corticomedullary differentiation. The patient immediately received haemodialysis. Post dialysis, potassium corrected $(5.0 \mathrm{mEq} / \mathrm{L})$ and ECG showed sinus rhythm and normalisation of the QRS interval and $\mathrm{P}$ and $\mathrm{T}$ waves (figure 2). She was discharged on maintenance haemodialysis for chronic kidney disease stage 5 .

Hyperkalaemia is associated with various ECG changes, loosely correlated with absolute value and rate of rising serum potassium. ${ }^{12}$ Tall, 'peaked' $\mathrm{T}$ waves with a narrow base typically appear as the earliest and the most common ECG abnormality, predominantly seen in the precordial leads $\mathrm{V}_{2}-$ $\mathrm{V}_{4}$. The greater degree of hyperkalaemia causes conduction disturbances with atrioventricular block manifesting as PR interval prolongation. Further, block in the distal His or bundle branches manifests as widening of QRS. ${ }^{3}$ Sinoatrial node involvement causes P waves' amplitude reduction, and with

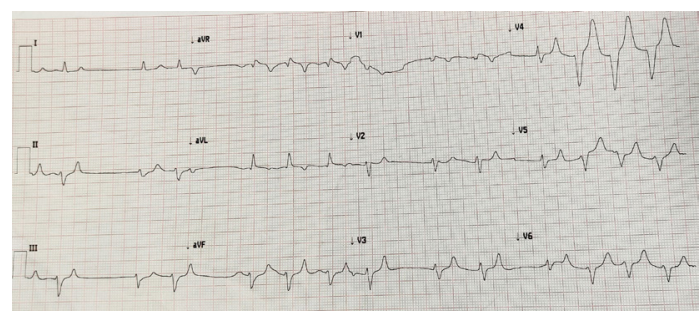

Figure 1 Electrocardiography showing irregular, wide QRS escape rhythms with no distinct $P$ waves and peaked T waves.

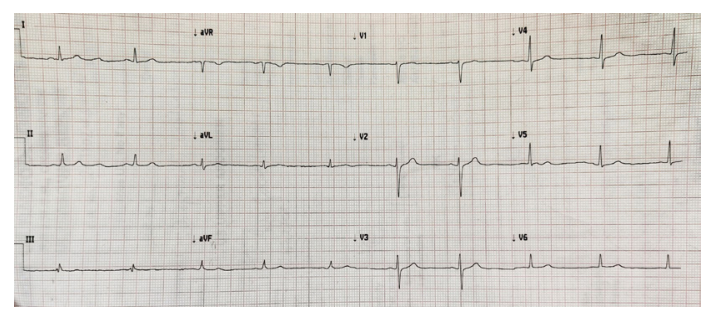

Figure 2 Postdialysis electrocardiography showing sinus rhythm with normalisation of the QRS interval and $\mathrm{P}$ and $\mathrm{T}$ waves.

the disappearance of P waves, a wide QRS escape rhythm appears on ECG. The continuous widening of QRS until the merging of $S$ and $T$ waves results in a 'sine wave' pattern that typically shortly precedes ventricular tachyarrhythmia. ${ }^{1-3}$

\section{Learning points}

- Because hyperkalaemia is associated with various cardiac conduction abnormalities, an initial presentation of chronic kidney disease with hyperkalaemia may mimic a cardiac emergency, especially in older adults.

- Prompt recognition of hyperkalaemia-related electrocardiography changes is life-saving.

Contributors AJ: Collected data and drafted the manuscript. SS: Drafted the manuscript. PD: Revised the manuscript. AKP: Conceived the idea and revised the manuscript.

Funding The authors have not declared a specific grant for this research from any funding agency in the public, commercial or not-for-profit sectors.

Competing interests None declared.

Patient consent for publication Parents/Guardians consent obtained

Provenance and peer review Not commissioned; externally peer reviewed.

\section{ORCID iDs}

Ashish Jindal http://orcid.org/0000-0002-4413-9368

Ashok Kumar Pannu http://orcid.org/0000-0002-4476-3478

\section{REFERENCES}

1 Medford-Davis L, Rafique Z. Derangements of potassium. Emerg Med Clin North Am 2014;32:329-47.

2 Alfonzo AVM, Isles C, Geddes C, et al. Potassium disorders-clinical spectrum and emergency management. Resuscitation 2006;70:10-25.

3 Montford JR, Linas S. How dangerous is hyperkalemia? J Am Soc Nephrol 2017;28:3155-65. 
Copyright 2021 BMJ Publishing Group. All rights reserved. For permission to reuse any of this content visit https://www.bmj.com/company/products-services/rights-and-licensing/permissions/

BMJ Case Report Fellows may re-use this article for personal use and teaching without any further permission.

Become a Fellow of BMJ Case Reports today and you can:

- Submit as many cases as you like

Enjoy fast sympathetic peer review and rapid publication of accepted articles

Access all the published articles

Re-use any of the published material for personal use and teaching without further permission

Customer Service

If you have any further queries about your subscription, please contact our customer services team on +44 (0) 2071111105 or via email at support@bmj.com.

Visit casereports.bmj.com for more articles like this and to become a Fellow 